\title{
Communal therapeutic mobility in group walking: a meta-ethnography
}

Tessa M Pollard ${ }^{\mathrm{a}}$, Cornelia Guell ${ }^{\mathrm{b}}$, Stephanie Morris ${ }^{\mathrm{a}}$

aDepartment of Anthropology and Wolfson Research Institute for Health and Wellbeing Durham University

Dawson Building, South Road

Durham

DH1 3LE

UK

University of Exeter Medical School

Knowledge Spa

Royal Cornwall Hospital

Truro

TR1 3HD

UK

${ }^{*}$ Corresponding author.

t.m.pollard@durham.ac.uk

c.guell@exeter.ac.uk

stephanie.I.morris@durham.ac.uk 


\begin{abstract}
Increased attention to links between walking, health and wellbeing have contributed to a growth in the number of walking groups meeting on a regular basis to offer short, social walks. Walking group interventions are known to increase physical activity and to have wide-ranging health benefits, and there is evidence that drop out is generally low. The aim of this paper is to synthesise qualitative research on experiences and perceptions of group walking in order to develop a new conceptual understanding of the group walking experience. We conducted a systematic search of the literature and identified 22 such studies which we synthesised using meta-ethnography. Included studies were conducted in the UK, USA, Australia and Ireland. Most reported research was undertaken with outdoor walking groups, some of which catered specifically for people who shared a disease experience or a disability. A smaller number of studies examined indoor mall walking groups, while two looked at perceptions of non-participants of group walking as a potential activity. From the original constructs identified in the papers we derived five higher order constructs: seeking and enjoying health and fitness, attachment to walking, providing purpose and confidence, mobile companionship and a peaceful and contemplative shared respite from everyday life. We argue that participating in a walking group provides a set of experiences that together constitute a specific form of shared or communal therapeutic mobility that is not simply the accumulation of the constructs we have outlined. Rather, we suggest that an initial instrumental and disciplinary focus on health and fitness is transformed through the experience of group walking into a shared meaningful and enjoyable practice; an emergent communal therapeutic mobility, which recruits and retains large numbers of group walkers. However, this communal therapeutic mobility is not equally accessible to all.
\end{abstract}

\title{
Keywords
}

walking; walking groups; therapeutic mobilities; pilgrimage; communitas; meta-ethnography; qualitative synthesis 


\section{Introduction}

Systematic reviews have shown that participating in a walking group increases physical activity (Kassavou et al., 2013) and improves the physical and mental health of participants, including reducing blood pressure, total cholesterol and depressive symptoms (Farren et al., 201; Hanson and Jones, 2015). These findings, and increased attention more generally to links between walking, health and wellbeing (Morris and Hardman, 1997) have contributed to a growth in the number of walking groups. In England, Walking for Health oversees free, weekly outdoor group walks led by trained walk leaders, with 70,000 regular participants (Walking for Health, 2013). In Australia, Heart Foundation Walking has walking groups attended by over 22,000 regular walkers (Ball et al., 2017). In the US, Canada and Australia, group walking in shopping malls for middle-aged and older adults is well established, often taking place on a daily basis in the early morning before shops have opened (Belza et al., 2015). Considered as a public health intervention, walking groups are successful both in contributing to improved health and wellbeing and in appealing to large numbers of people, with low levels of drop out (Hanson and Jones, 2015).

Gatrell's (2013) concept of 'therapeutic mobilities' makes an important contribution to understanding walking as a successful route to health and wellbeing. Building on Gesler's (1996) seminal work on therapeutic landscapes and the mobilities turn in the social sciences (Cresswell, 2006; Sheller and Urry, 2006), Gatrell identified three key aspects of therapeutic mobilities: activity, context and sociality, each of which he considers separately. In relation to activity, Gatrell highlighted the evidence that movement itself improves physical and mental health and drew attention to the therapeutic value of the slowness and rhythmicity of walking. He went on to outline the importance of the context of walking, particularly the value of 'walkable' streets and of 'nature'. In his consideration of the contribution of sociality to therapeutic mobility he focused on friendly encounters with other walkers on the street or in the rural landscape, and on walking with familiar others (including pet dogs), citing Middleton's (2009) work on how couples walking together to work "have some of our best talks on our morning walks". He briefly notes that that there may be additional benefits from moving in groups, but does not explore how therapeutic mobility might be experienced in group walking.

As Doughty (2013) emphasises and Gatrell acknowledges, it is important to consider the active body, the walking context and the social body together, in a more relational manner, in order to understand how walking can afford a therapeutic experience. For example, Guell et al.'s (2012) work draws attention to the sensory connection of the active body with place that is facilitated by walking, showing how commuters walking to work reflected on the sensual experience of their slow journey and especially of a connection with 'nature' that helped them find a buffer ('time out') between home and work life. Walking with others adds a shared sensory connection with place (Sharpley and Jepson, 2011) and between bodies, that may, for example, be experienced as a shared rhythmicity (Phoenix and Bell, 2019). It is in this assemblage of mobile bodies and place that we begin to appreciate fully the potential affordances of group walking.

\section{Aim}

Increasingly, qualitative research, including ethnographic research, is being used as part of the process evaluation of complex interventions, to 'open up the black box' and explore how interventions are experienced and 'work' for participants (Morgan-Trimmer and Wood, 2016). A number of such studies have been conducted on group walking, and further qualitative research on group walking has been undertaken by social scientists interested in exploring health practices from a less applied perspective. The aim of this paper is to synthesise existing qualitative research on 
understandings and experiences of group walking in order to develop a new conceptual understanding of the group walking experience and, in so doing, to improve our understanding of an apparently successful intervention. To achieve this, we chose to conduct a synthesis using metaethnography (Noblit and Hare, 1988). Noblit and Hare (1988) developed this explicitly interpretative approach to research synthesis to facilitate conceptual translation between studies (Flemming et al., 2012), distinguishing it from methods of synthesis that rely on aggregation (Britten et al., 2002). In this way, meta-ethnography retains the interpretive, inductive approach of ethnography, while treating the interpretations offered by the authors of the original studies as data to be synthesised.

\section{Methods}

\section{Study design}

We conducted a systematic search to identify qualitative studies of experiences and understandings of walking groups, including both studies of participants and studies investigating the responses of non-participants to the possibility of engaging with a walking group. We then undertook three phases of meta-ethnography; reading the studies to develop a good understanding of each one and compiling a list of the second order constructs, that is, those identified by the authors of each study, translating the studies into one another by grouping the second order constructs into our own third order constructs, and synthesising the studies by developing a line of argument.

\section{Identification of studies}

We conducted a comprehensive search to identify all previous qualitative studies of walking groups reported in English so that we could draw on all the evidence available to us. Studies were identified through searches of electronic databases, scanning reference lists of eligible papers and by drawing on our familiarity with qualitative research on walking groups as authors of papers eligible for inclusion (one published (Hanson et al., 2016), and one under revision for publication (now published) (Morris et al., 2019)). The initial search terms used were "walking group(s), group walk(s), walking in groups, walking in a group". Trial searches were conducted on Web of Science Core Collections, and having noted some papers in initial results on mall walking (in groups), we then added the terms "mall walking" and "walking in malls". Final searches with all terms were conducted in Web of Science Core Collections, PubMed, Scopus, CINAHL, SPORTDiscus, Anthropology Plus and OpenGrey. All databases were searched from inception until July 2019. Studies of walking group leaders or administrators only were not included. Studies of Nordic walking groups were not included because of the requirement for specialist equipment and technique.

The first author reviewed the abstracts of all unique publications retrieved and those deemed potentially eligible were read in full by the same author and a research assistant to determine inclusion. The bibliographies of included papers were then searched to identify further eligible papers.

\section{Quality appraisal}

Following Malpass et al. (2009), we assessed both the methodological rigour and the conceptual richness of each study. As is often the case in meta-ethnography, our aim was to ensure that insightful studies were only excluded if 'fatally flawed' and that the findings of conceptually richer studies were prioritised in the analysis (Young et al., 2018). To assess methodological rigour we used the Critical Appraisal Skills Programme (CASP) tool for qualitative research, although we did not assign a numerical score (Malpass et al., 2009). The main aim of this process was to identify and 
exclude studies that were 'fatally flawed' in their design, conduct or reporting. We then assessed conceptual richness, coming to a judgement of whether a paper should be considered 'key' or 'satisfactory' (Malpass et al., 2009; Young et al., 2018). Key papers were conceptually rich and had the potential to make an important contribution to the synthesis, while the contribution of 'satisfactory' papers was considered likely to be less important, tending to present descriptions of participants' contributions rather than a conceptual analysis. Two authors (TP and CG) independently undertook this process and discrepancies were discussed until agreement was reached. Key papers were prioritised in the synthesis, as outlined below.

\section{Synthesis}

All publications were read and re-read by all three authors to identify the main concepts. We excluded results based on data from walk leaders or organisers only. Two authors (TP and CG) then went on to describe second order constructs, that is, the researchers' interpretations of the data, and to discuss how the studies were related to one another and how this would inform our analysis. In focusing on second order constructs rather than also including first order constructs (the participants' interpretations in their own words), we follow Toye et al. (2014), who note that only the authors of the original study have access to all the knowledge and data collected, making it inappropriate for a different set of researchers to try to re-organise their findings. The two authors then agreed a final list of constructs. We also noted how the studies differed in research design, context (such as type of walking group and outdoor versus indoor setting), characteristics of participants, date and location of study, and overarching explanations (where offered).

The next step was to translate the qualitative studies into one another by comparing constructs and organising them into conceptual categories, or third order constructs. In order to prioritise findings from the richest papers, we started this process with the 'key' papers, then moving on to 'satisfactory' papers, although we continually revisited constructs and the original papers during the process. We wrote a description for each construct. The first author undertook this process first, and it was then repeated by a second author (CG), with reference to the first author's results. The two repeatedly discussed their results until a consensus was reached.

The final stage of a meta-ethnography is to synthesise these third order constructs. We aimed to develop a line of argument synthesis by developing 'a grounded theory that puts the similarities and differences between studies into interpretive order' (Noblit and Hare, 1988, p64). This approach is used to provide a fresh interpretation, going further than simple translation and offering a fuller account than in any of the contributing studies. The first author took the lead on developing a line of argument in discussion with the other two authors to provide an overarching understanding of the way participants experience walking groups. We carefully considered contradictory evidence, and together discussed and challenged our emerging line of argument, taking into consideration variation between groups in relation to factors such as setting (e.g. indoor versus outdoor) and the characteristics of participants (e.g. patient groups versus general population groups).

\section{Findings}

\section{Study characteristics}

The electronic searches yielded 747 unique records of potentially relevant publications. Based on abstract review 711 were excluded, with 31 retained for full text review. Of these, 4 papers presented only quantitative data, 3 dealt with walking but not in groups, 2 considered walking groups only as part of a wider intervention and 1 included no primary data. Thus 21 were deemed eligible 
for inclusion in the review. Searching the bibliographies of these papers revealed 2 further studies eligible for inclusion, and we also included our own (at that time under final review for publication) study, leading to a total of 24 included publications, reporting the results of 22 different studies (Table 1). Ten studies were categorised as key and twelve as satisfactory (Table 1). Twenty studies reported the experiences of people who were, or had been, members of walking groups (16 on members of outdoor walking groups, 3 on members of indoor walking groups and 2 on groups that walked outdoors and indoors) and 2 studies reported on data from potential walkers (Table 1). Not all studies described key characteristics of participants. Of studies of the experiences of walkers that reported on gender, 14 included more women than men (ranging from 59\% to 91\% women) while 3 included more men than women (these were a mall-walking group, a group for visually impaired walkers, and a group attached to a mental health care day centre). A wide age range of walkers was represented, but many walkers were in middle or old-age, with 9 studies of walkers explicitly saying that participants were mostly or all aged over 50 years. Some studies included data collected from both walkers or potential walkers and walk leaders. Where the data from walk leaders was analysed separately, we referred only to the analysis of data from walkers or potential walkers.

We found considerable overlap among the studies in their results, with most identifying health and social benefits of group walking. Many studies took an individualised behavioural approach and separately analysed health and social motivations articulated by individuals for joining and remaining in walking groups, but the richer studies tended to draw on participant observation as well as interviews, considered group walking as an embodied and relational practice, and did not separate the processes of joining and continuing with a group. Some papers focused on walking groups set up specifically for those with health problems and their analyses focused more heavily on the health benefits. Given the complementarity between studies, we felt confident in pursuing a line of argument' analysis, but were careful to pay attention to contradictory evidence.

\section{Translation}

We identified 170 second order constructs, that is constructs developed by the authors of the included papers. Inevitably, given the variation in the richness of the analysis offered by papers, some constructs were relatively rich in meaning, while others were thinner, based merely on describing collated information from participants.

We considered that it would be inappropriate to separate out data on the processes of joining and continuing with a walking group, partly because the recollections of members on the process of joining would inevitably be to some extent outcomes of their engagement with the group (Blue et al., 2016), noting that motives should be conceived of as difficult to articulate, continuously shifting and reforming and liable to be "redefined in reminiscence" (O'Neill and Roberts, 2020, p120). We did not therefore reproduce the separation in some of the papers between constructs linked with the processes of joining and continuing with a walking group, although in our summaries of second order constructs we paid careful attention to the ways in which understandings of group walking evolve over time for walkers.

Having identified all the second order constructs present in the contributing papers, we undertook the translation process, with an initial focus on the key papers, and identified 11 rich third order (i.e. our own) constructs (Table 2). We found that many second order constructs from the satisfactory papers easily found a place within these third order constructs and all the final third order constructs were informed by multiple papers. There were additional thinner second order constructs that were shared across a number of papers and we noted these shared findings separately. Yet other thinner second order constructs were not shared between papers and did not contribute to the final analysis. 
The second order constructs were broadly very consistent and coherent, although we also noted some disconfirming cases (France et al., 2019) that directly contradicted the more commonly shared findings, and we retained these in our analysis.

\section{Synthesised translations}

At the final stage of the synthesis we identified five higher order constructs (Table 2 and below) which we integrated to form a synthesised line of argument identifying group walking as a specific form of communal therapeutic mobility. We outline and discuss the five third order constructs below before presenting our final line of argument. Where we reproduce quotations from study participants, as used by the original authors, we show them in italics with double quotation marks. Where we quote directly the words of the original authors, we use italics with single quotation marks.

\section{Seeking and enjoying health and fitness}

We found that seeking and enjoying health and fitness featured as an important reason for people to engage with walking groups. This seems particularly key in the process of joining a group, which participants saw as a way to 'stay healthy', 'lose weight' and 'keep fit' (Warin et al., 2008). For some walkers the need to undertake more exercise was linked to increasing age, as one of the participants in Copelton's study (2010) noted, "I should be doing exercise at my age. It's good for me." Others joined a group because they saw it as a way of managing a chronic condition, such as type 2 diabetes or depression, or as part of recovery from illness. Indeed, some groups catered specifically for those affected by chronic conditions. In some cases, physical activity had been 'prescribed' by a health professional and/or was strongly encouraged by a family member following a diagnosis or with increasing age. Walkers appreciated embodied changes experienced after joining a group, particularly feeling fitter, but also more specific bodily changes such as reduced breathlessness and weight loss.

Priest (2007) develops the notion of 'striving' in her analysis of data from participant observation with a walking group organised by a mental health day service in the UK, referring to people actively working to make themselves feel better. Importantly, this sense of striving was shared; in the words of one participant "we've all had mental health issues - we're all trying to recover and do our best to move on". For these walkers, efforts were being made to work on their mental health not only by exercising, but also by, for example, practising interactions with other people. This concept captures the sense of work and effort towards improved health that emerged in our synthesis, although it is important to reiterate that this was a factor that was much more important in the early stages of joining a walking group and there is a clear sense of such ideas fading over time, becoming secondary to other 'benefits' of group walking. Priest's notion of striving was not only connected to health, however, and we return to it below.

However, not all group members felt a strong commitment to improving their health through walking. Some members of a walking group who had been referred for exercise by their GPs felt that walking was not a 'purposeful' activity (Hanson et al., 2016) and some older participants who lived in a continuing care retirement community, and were probably therefore relatively frail, felt that it was inappropriate, unnecessary or risky and produced unpleasant sensations (Resnick and Spellbring, 2000).

\section{Attachment to walking}

A positive prior embodied experience and understanding of walking emerged as an important factor for participants in a few studies. Walking was generally mentioned as being familiar and enjoyable 
(Grant et al., 2017a; Hynds and Allibone, 2009; Resnick and Spellbring, 2000) and for some walkers a rediscovery of walking was greatly appreciated (Hanson et al., 2016). Two studies note that joining a walking group was a preferred option compared with the option to join a gym class because there was less concern about being 'judged' (Copelton, 2010), suggesting that people were more confident about walking, as a familiar everyday activity, than about engaging with an activity that required unfamiliar expertise.

However, Resnick and Spellbring (2000) also reported that some of their participants in the continuing care retirement community had not previously walked or exercised, or felt that walking was no longer appropriate in old age, and Currie et al. (2016) found that some mothers living in deprived areas of Scotland who were not members of walking groups (but were asked about the likely acceptability of walking groups during pregnancy) felt that walking was not an appealing or fun activity but was functional or ordinary.

\section{Providing purpose and confidence}

Group walking tended to become incorporated into a weekly routine, providing a valued sense of structure, and was also experienced as an achievement, leaving participants feeling energised and confident. As one of Grant et al.'s health walk participants (2017a) said "That's what you do on a Monday morning, and it's just part of the rhythm of your life... a lovely way to start the week". Some walkers valued replacing lost routines of working life following retirement with the new routine of group walking, as Duncan et al (1994) reported for the mall walkers they studied, many of whom turned up to walk early every morning from Monday to Friday. Attending the walk became a welcome obligation.

Macpherson (2017) highlighted the sense of achievement and pride of visually impaired walkers and their guides walking on reaching a mountain summit, but this feeling was not unique to this group, and was also felt by members of Walking for Health groups who undertook much gentler walks; as a participant in Hynds and Allibone's (2009) study said: "When I've finished, it's a job well done and I can feel proud of myself". These accounts partly reflect a task-oriented or instrumental approach to the group walk, but overall there was a broader sense of obtaining ' $a$ 'boost"' (Morris et al., 2019) or, returning to Priest's (2007) concept of striving, a sense that 'there is something intrinsically rewarding about striving.' Most studies did not report that this accomplishment being shared was particularly important, although Priest commented on the value of 'recognition of efforts made by other members of the group'.

In contrast, mothers from deprived areas of Scotland, who were asked to consider the acceptability of walking groups noted that they would not want to make a commitment to attend regularly as they might not always want to go along to a walk, for example in bad weather.

\section{A peaceful and contemplative shared respite from everyday life}

Here we draw together two translations: a haven away from everyday life, which is enhanced, for outdoor walkers, by experiencing connections with 'nature'. While most papers explored these concepts separately, Doughty (2013) also draws them together under the concept of 'sharing therapeutic space'. She notes that several participants referenced walking "mindlessly", and discusses the 'sense of presence in one's own body and in the moment' that provides a respite from everyday cares, together with a 'shared orientation toward improving wellbeing and happiness' in the context of moving together through the countryside. We consider that Priest's (2007) constructs 'getting away', 'finding meaning' and 'closer to what is more natural' also cluster together under this higher order construct. Indeed, Priest notes that getting away from 'unnatural environments' can be part of getting away from difficult everyday lives. Being closer to nature offered 'fresh air' and, as a 
walker in her study says, "Less houses or society and more wandering through fields and over stiles means less anxiety and more mental freeness. Less self-consciousness". Similarly, Ireland et al. (2019) found that for women affected by breast cancer, 'movement from the urban to rural - unnatural to natural landscape - with all its attendant sensations, was conducive to feelings of calmness, healing, and freedom'. For the visually impaired walkers who walked in the countryside with a sighted guide (Macpherson, 2017), there was an unaccustomed sense of freedom, but also of 'escape from known routes in urban and suburban areas'. Thus, there is a consistent association between escape from everyday life and from urban environments, and an appreciation of a period of peace and contemplation that is partly ascribable to moving purposefully but 'mindlessly' with other bodies through green or, in one case coastal (Hanson et al., 2016), environments.

While 'nature' is generally greatly appreciated, some kinds of nature were experienced negatively by some walkers. Iwata et al.'s (2016) participants belonged to a "woodland for health" programme in Ireland for individuals experiencing enduring mental ill-health. Echoing other studies, many participants experienced a sense of peace and calm, enjoying the beauty and quietness of the forest, the lack of people, and the sense of escape and freedom away from everyday life. However, one participant felt cold and uncomfortable when walking through tall and dense conifer plantations, and other participants mentioned the darkness of these sites. For Walking for Health walkers in urban areas in England, pockets of nature were generally enjoyed, but some commented that even beautiful areas could become boring if the route was not varied (Hynds and Allibone, 2009).

For shopping-mall walkers, of course, the walking environment is very different. While mall walkers did not find the environment through which they were moving attractive, a sense of peace and quiet in malls that were not yet open to shoppers was appreciated.

\section{Mobile companionship}

Here we bring together four translations that together constitute the particular form of companionship that walking in a group appears to offer. These are: experiencing social connection, experiencing acceptance, experiencing fleeting sociability and belonging and feeling safe. It is this walking companionship that emerges clearly as the most powerful experience of group walking.

Nearly all the papers included in our analysis highlighted the importance of social connection. As Warin et al. (2008) put it 'it is the network of relationships that sustain the event', illustrating their point with observations of walkers offering support ("we'll be thinking of you") to their companions. Similarly, Copelton (2009) noted that walkers emphasised the 'camaraderie' afforded by their group. Importantly, this camaraderie is specific to the walking group experience. As Doughty (2013) argues, 'the moving body does something to our sociability', partly by relaxing social norms around talking and silence. The absence of eye contact and the companionship of moving together reduces the intensity of interaction. Ireland et al. (2018) use the phrase 'shoulder-to-shoulder support' to describe how this phenomenon was realised for women affected by breast cancer, in this case enhanced by a shared experience of serious illness.

A second element of walking companionship is a sense of acceptance and belonging. Here we place Priest's (2007) 'being part'. This feeling of belonging extended beyond the group itself to the landscape, or even, as one participant said "being one with it all". Priest develops a second construct, 'being me', which we group with 'being part' because it is also about gaining a feeling of belonging; being part of the group (in this case of people with mental health problems) helped people to feel the same as others and thus to accept themselves. Ireland et al (2018) reference a sense of 'fellowship' with other group members with a shared cancer experience. However, the feeling of acceptance and belonging, while strongest in groups set up for those with a particular 
health problem, was not unique to them but also emerged in other groups from the shared weekly or daily routine of walking together.

A particular feature of walking and talking together within a group is the opportunity for 'fleeting sociability' (Doughty, 2013). This was best developed by Doughty, but others observe a similar phenomenon, including later studies that pick up the concept from Doughty. Walking groups are characterised by a switching between companions and conversational topic, as pairs or small groups spend some time together and then a change of direction or pace results in a natural shifting of bodies to a different formation. This makes for a transient and light form of social connection that was particularly appreciated by walkers. Doughty also shows how communication between walkers did not depend on conversation, as the body responds to the presence of another walker in, for example, an alignment of pace.

We also include our translation 'feeling safe' under the heading of walking companionship because a feeling of safety and security, which was important to walkers, emerges from the companionship of fellow walkers. Again, being in a group of people with shared experience of illness and distress was important in generating security, as was the presence of a leader in the outdoor groups. As Priest (2007) highlights, being outside in 'nature' lent a feeling of security because nature was predictable and, for one participant "homely". Morris et al. (2019) show that for one group attached to a community centre which included a number of people with long term illness or in long-term unemployment, walking with people who were already familiar was important for generating a secure environment. 'Safety in numbers' was a more prosaic aspect of this experience, particularly for women walking in the countryside (e.g. South, 2012). For mall walkers, a safe and sheltered environment was particularly valued. Malls offered traffic-free zones, were usually only open to walkers (at the times they walked), were climate-controlled and provided a flat walking surface. These features were important to the older, more frail walkers who enjoyed mall walking.

Conversely, there was evidence of social apprehension, particularly concerns about 'fitting in' when contemplating joining a group. When asked about the idea of joining a walking group during pregnancy, women felt that companionship with women in the same situation could be valuable, but others were afraid that "no-one might speak to you" or "you turn up and you don't know anybody and it's awkward" (Currie et al., 2016). Similar concerns were experienced by walkers who had chosen the option of joining a walking group having been referred for exercise, with the first session 'a hurdle to be crossed' (Hanson et al., 2016). These problems were thought to be greater for those who are not 'naturally gregarious' (Phillips et al., 2011) and in this study walkers also reported adverse experiences of 'cliques'. For one non-member of a group, walking alone was actively preferred: "I prefer the solitude of walking" (Morris et al., 2019) (although Hanson et al. (2016) found that some walking group members enjoyed walking with others without socialising with them).

\section{Overall Line of Argument}

\section{A communal therapeutic mobility}

We argue that participating in a walking group provides a set of experiences that together constitute a specific form of shared or communal therapeutic mobility, which is something more than the therapeutic mobility described by Gatrell (2013). It is not simply the accumulation of the constructs we have outlined. Rather, we suggest that an initial focus on health and fitness and, often, attachment to walking, is transformed through the experience of group walking into an emergent communal therapeutic mobility. Walkers gain a sense of purpose and confidence, and appreciate mobile companionship and a peaceful and contemplative shared respite from everyday life, and in 
this way group walking becomes an important and enjoyable part of walkers' lives. This is not to say that the initial focus on health and fitness or attachment to walking falls away and should simply be considered as the 'motivation' that led to joining a walking group in the first place, but that over time walkers change their understanding of group walking from initially considering it as an instrumental way to gain health and fitness, to valuing it for the experience itself, while an association with health and understanding of walking as good and natural continues to underpin this experience. In this way, the five separate higher-order constructs we have identified in fact overlap and interact and are merged in the experience of group walking.

\section{Discussion}

The process of synthesising qualitative research on group walking through meta-ethnography led us to a line of argument based on a strong consensus across previous studies. Our analysis demonstrates that members of walking groups enjoy a communal therapeutic mobility, that develops over time for group walkers. We argue that it emerges from a shared instrumental, disciplinary approach to improving health and an attachment to walking, which is then transformed through the experiences we have identified into a shared meaningful and enjoyable practice.

A concern with seeking and enjoying health and fitness through walking reflects responses of participants (and often authors) to responsibilising messages about the importance of keeping active in order to pursue good health, and to a recent emphasis within public health promotion on walking as an accessible form of health-promoting physical activity (Carpenter, 2013). Critical public health scholars highlight how the promotion of physical activity emphasises a moral responsibility to take exercise (Lupton, 1995), and argue that such neo-liberal rationalities increasingly regulate the way we think about physical activity practices such as walking (Fullagar, 2003). The attachment to walking as an appropriate, enjoyable way to pursue health that was evident in a number of papers can in turn be linked to a long literary history characterising walking as a virtuous activity that is simple, good, natural and healthy (Mitchell, 1979). A focus on walking for health also reflects the badging and advertising associated with many of the walks; a number of the British studies involved 'Walking for Health' groups, and some groups studied catered for people with particular diagnoses.

Over time a sense of purpose and confidence emerged for walkers within a regular routine of group walking. At its simplest this might be about successfully climbing a hill or completing a walk, but a more general sense of commitment and accomplishment was described, related to the weekly, or sometimes more frequent, effort of joining the walk (particularly for those with mental health problems) and the physical effort of walking. The familiarity and predictability of the rhythm of this routine was in itself pleasurable (Phoenix and Bell 2019). Others have made similar observations with respect to other forms of physical activity. For example, Lloyd et al. (2016) highlight the ways in which leisure time physical activity made women feel capable, and South African women who participated in competitive line dancing also enjoyed a feeling of confidence and accomplishment (Nadasen, 2008).

The concept of group walking as a peaceful and contemplative shared respite from busy modern lives reflects Romantic notions of walking as restorative (Edensor, 2000), and the idea within industrial society that walking, especially in the countryside, is a valuable way to preserve what has been lost (Urry, 2007). Edensor (2000) points to the ways in which the walking body's engagement with terrain, weather and other species produces a mindfulness focused on the sensations and strategic responses required that is experienced as restorative. He argues that in this way the material, spatial and sensual experience of walking in the countryside produces particular types of bodily reactions that "disrupt ordinary urban walking habits" and can "awaken the senses", stimulating reflexivity. Ingold 
(2010) explores walking, through the walking body's relationship with the ground, paths and weather, as a process of thinking and knowing. The slow rhythm of walking contributes to a feeling of stillness and escape and also enhances the feeling of connection with the, often 'natural', environment (Guell et al., 2012; Gatrell, 2013). These feelings are further enhanced in the walking group experience because they are shared, so that there is a sense of connection with both walking companions and the surrounding environment.

In this understanding of group walking as a contemplative shared respite we see elements of the liminoidity ascribed to pilgrimage by Turner and Turner (1978). Liminoidity is characterised as a potentially transformational voluntary separation from society, a powerful and bounded form of symbolic engagement, leading to an unusually intense experience of 'flow' (Spiegel, 2011; Coleman, 2019). For example, in her ethnographic account of Swedish pilgrims following El Camino (the Way), Gemzöe (2014) concludes that "the Camino is represented as a liminoid space, existing outside ordinary time and space, and it is in this "out there" that a healing of self can be experienced". Similarly, Frey (1998, p73) describes pilgrims' "strong sense of the "here and now"' and of an "“out of time" quality", as well as a feeling of connection with place, with senses open to the environment. Slavin (2003) suggested that the pilgrims he met were "in a place radically, ontologically different from places bounded by space and time", citing a study participant who said "The point is not to go... the point is to be...". However, it is with the 'smaller' version of liminoidity seen in Sallnow's (1987) more prosaic account of the experiences of Andean pilgrims as embedded in, rather than entirely separate from, everyday life, that we see the strongest parallels to the experiences of walking group members. In line with other accounts of pilgrimage, Sallnow observes a release from the everyday, but notes that it can be "a recurring event, building up local members and putting down strong roots in local networks of cooperation and competition" (Coleman and Eade, 2004).

It is walking with others that is the defining characteristic of group walking, and the importance of this particular form of mobile companionship shines through in the analyses offered by the papers we synthesised. In walking groups for people with specific shared experiences, such as mental health problems, breast cancer or impaired vision, there is a further element of a commonality and distinction from others. In the sense of social connection and acceptance and belonging that characterises this sociality, we see a further clear parallel with the experiences of pilgrims conceptualised by the Turners as communitas, described by Coleman (2002) as "the individual pilgrim's temporary transition away from mundane structures and social interdependence into a looser commonality of feeling". Winkelman and Dubisch (2005) have previously highlighted the therapeutic potential of communitas, suggesting that "the sense of community with fellow pilgrims on a common mission is central to the healing power of pilgrimage" (pxxii). However, the mobile companionship described in the original studies is 'light', emerging from the 'fleeting sociability' of walking together in continually reforming small groups and, crucially, for a limited period of time, and in this it contrasts with the intensity of experience normally associated with the communitas of pilgrimage. Thus, we find the concept of communitas illuminating here, but do not suggest that it can be transposed directly into the walking group context.

In group walking then, an individualised focus on health and managing risk through a 'good' activity becomes an experience of wellbeing that can be understood as emerging from relationships formed in a temporary shared enterprise (Atkinson et al., 2019; White, 2017). The concept of communal therapeutic mobility extends Gatrell's (2013) notion of therapeutic mobility, and we have deliberately chosen terminology that links it back to communitas. There is a direct parallel with pilgrimage, a journey with sacred and religious intent, that can become a liminoid space offering an experience of communitas that results in a sense of spiritual renewal (Gemzöe, 2014). Thus we see group walking as creating a therapeutic space of communal wellbeing that emerges from an 
assemblage of people and the environment through which they move, a sense to which the green landscapes, chosen by many outdoor walking groups, contributes. Further, we suggest that other forms of communal therapeutic mobility are likely to be seen in other contexts in which people move together.

Ideas held about the 'benefits' of walking groups before joining contribute to the experience of communal therapeutic mobility and we do not see in the studies synthesised here evidence of resistance to or a critical awareness of disciplinary practices of power (Markula, 2004). Rather the experience of communal therapeutic mobility emerges from a disciplinary starting point. Similarly, Wiltshire et al., (2017) show that for weekly parkrun participants, running as a collective acts to soften the potentially harmful impact of the moral imperative to perform physical activity for health reasons, but does not extend to resistance to such disciplinary practices. They term this experience 'collective bodywork', writing that "parkrun appears to not merely exploit the individualised desires to be physically active, but rather to nourish participants' desires to enact relationships with family and friends, to provide and receive support and to strive towards goals as part of a group".

We acknowledge variation in the experience of communal therapeutic mobility between walking groups, which, while sharing key characteristics, are not homogenous. In particular, there is an important distinction between outdoor groups and mall-walking groups in relation to the environments in which they walk, and also, often, in the frequency of walks (often weekly for outdoor groups and daily for mall-based groups). We suggest that mall-walking groups experience a more restricted form of communal therapeutic mobility. However, mall-based groups are more accessible for, and valued by, older walkers.

We also acknowledge that, while clearly derived from our translations of the original studies, the experience of communal therapeutic mobility through walking group membership is not universal for all walkers and nor is it readily available to all. Walking interventions tend to recruit well-educated, middle-aged White women (Foster et al., 2011) and in a systematic review of the impact of walking groups on health, $76 \%$ of group participants in included studies were women, and the grand mean age of participants was 58 (Hanson and Jones, 2015). In studies included in our synthesis, the majority of walking group participants were also middle-aged and slightly older women, while most studies did not provide information on education or ethnicity. It is notable that two of the studies that contributed disconfirming concepts were of walking groups that did not fit this usual profile. Resnick and Spellbring (2000) studied members of a continuing care retirement community, with an average age of 81 , that included members who walked with assistive devices, and Hanson et al. (2016) studied a walking group whose members had been referred by their GPs in a socioeconomically deprived area of the UK. The authors of both these papers identified concerns amongst participants about walking as a route to health and fitness, and Hanson et al. also found worries about the social aspect of group walking. Further disconfirming concepts were contributed by two studies that asked non-members of walking groups to consider group walking. In one case participants were mothers from deprived areas of Scotland (Currie et al., 2016), while Browne et al. (2016) sought the views of a group of people with serious mental illness, most of whom were men and African-American. Both these authors identified social apprehensions about the process of joining a group.

The distinctive composition of walking groups and variation in their appeal to different groups is no doubt partly a consequence of the gendered, aged and classed nature of healthism and active aging discourses (Fullagar, 2003; Katz and Calasanti 2015), as well as of walking for leisure (Green, 2009), and of sociability (Cowan, 1991). Further, women are subject to constraints in their occupation of public space, contributing to a perception of risk that can restrict or impair the experience of walking 
alone (Schmucki, 2012), which is likely to increase the appeal of group walking. Morris et al. (2019) show how, partly because of these factors, group walking can become a 'lifeline' for women at moments of biographical disruption, including retirement. Conversely, for those without access to a car, walking can be experienced as a necessary and sometimes difficult or unpleasant mode of travel (Bostock, 2001; Green, 2009), potentially reducing the appeal of walking groups to the less advantaged. More prosaically, accessibility to disadvantaged groups may also be reduced by constraints such as access to walk starting points for those without a car (Grant et al., 2017a). It is not surprising, then, that group walking is more attractive and accessible for some than for others.

\section{Conclusion}

Based on a meta-ethnographic synthesis of original studies of walking groups, drawing on the analysis of the authors of the original studies, we have developed a novel understanding of the group walking experience as a form of communal therapeutic mobility. Walking with a group allows participants to convert a response to responsibilising messages to seek good health and fitness into an enjoyable and freeing practice. We do not suggest that group walking is the only context within which communal therapeutic mobility can be found, but that we have found rich evidence that walking groups provide a distinctive form of communal therapeutic mobility. This concept will be of value in relation to other forms of shared mobility with therapeutic intent and we encourage its mobilisation in other contexts, for example in relation to group running and cycling. We suggest that our analysis is illustrative of the strengths of meta-ethnography, demonstrating its capacity to build on a process of translation between studies to generate new insights based on a large body of evidence.

In synthesising a rich body of qualitative research we have made an important contribution to 'opening up the black box' of how walking group interventions 'work'. Walking groups are a valuable resource for many and make an important contribution to improved population health and wellbeing. An understanding of the value of communal therapeutic mobility has the potential to stimulate work to extend these opportunities, although such work will need to consider a complex range of factors that currently limit access to group walking.

\section{Acknowledgements}

We are very grateful to the Wolfson Research Institute for Health and Wellbeing at Durham University for funding the initial work on this review, to Janelle Wagnild for her assistance in identifying papers, and to Simon Coleman and Ben Hodapp for introducing us to the pilgrimage literature.

\section{Declarations of Interest}

None.

\section{References}

Atkinson, S., Bagnall, AM., Corcoran, R., South, J., Curtis, S., 2019. Being well together: individual subjective and community wellbeing. J. Happiness Stud. 21,1903-1921.

Ball, K., Abbott, G., Wilson, M., Chishol, M., Sahlqvist, S., 2017. How to get a nation walking: reach, retention, participant characteristic and program implications of Heart Foundation Walking, a nationwide Australian community-based walking program. Int. J. Behav. Nutr. Phys. Act. 14, 161. 
Belza, B., Allen, P., Brown, D.R., Farren, L., Janicek, S., Jones, D.L., King, D.K., Marquez, D.X., Miyawaki, C.E., Rosenberg, G., 2015. Mall Walking: A program resource guide. University of Washington Health Promotion Research Center, Seattle.

Belza, B., Miyawaki, C.E., Allen, P., King, D.K., Marquez, D.X., Jones, D.L., Janicek, S., Rosenberg, D., Brown, D.R., 2017. Building community: stakeholder perspectives on walking in malls and other venues. J. Aging Phys. Activ. 25, 510-524.

Blue, S., Shove, E., Carmona, C., Kelly, M.P., 2016. Theories of practice and public health: understanding (un)healthy practices. Crit. Public Health 26, 36-50.

Bostock, L., 2001. Pathways of disadvantage? Walking as a mode of transport among low-income mothers. Health Soc. Care Comm. 9, 11-18.

Britten, N., Campbell, R., Pope, C., Donovan, J., Morgan, M., Pill, R., 2002. Using meta ethnography to synthesise qualitative research: a worked example. J. Health Serv. Res. Po. 7, 209-215.

Browne, J., Mihas, P., Penn, D., 2016. Focus on exercise: client and clinician perspectives on exercise in individuals with serious mental illness. Community Ment. Health J. 52, 387-394.

Carpenter, M., 2013. From 'healthful exercise' to 'nature on prescription': the politics of urban green spaces and walking for health. Landscape Urban Plan. 118, 120-127.

Coleman, S., 2002. Do you believe in pilgrimage? Anthropol. Theor. 2, 355-368.

Coleman, S., 2019. From the liminal to the lateral: urban religion in English cathedrals. Tourism Geogr. 21, 384-404.

Coleman, S., Eade, J., 2004. Introduction: reframing pilgrimage, in Coleman, S., Eade, J. (Eds.) Reframing Pilgrimage: Cultures in Motion. Routledge, London, pp. 1-25.

Copelton, D.A., 2010. Output that counts: pedometers, sociability and the contested terrain of older adult fitness walking. Sociol. Health III. 32, 304-318.

Cresswell, T., 2006. On the Move: Mobility in the Modern Western World. Routledge, London.

Cowan, J., 1991. Going out for coffee? Contesting the grounds of gendered pleasures in everyday sociability, in Loizos, P., Papataxiarchis, E. (Eds) Contested Identities: Gender and Kinship in Modern Greece. Princeton University Press, Princeton, pp. 180-202.

Currie, S., Gray, C., Shepherd, A., McInnes, R.J., 2016. Antenatal physical activity: a qualitative study exploring women's experiences and the acceptability of antenatal walking groups. BMC Pregnancy Childb. 16, 182.

Doughty, K. 2013. Walking together: the embodied and mobile production of a therapeutic landscape. Health Place 24, 140-146.

Duncan, H.H., Travis, S.S., McAuley, W.J., 1994. The meaning and motivation for mall walking among older adults. Act. Adapt. Aging 19, 37-52. 
Edensor, T., 2000. Walking in the British countryside: reflexivity, embodied practices and ways to escape. Body Society 6, 81-106.

Farren, L., Belza, B., Allen, P., Brolliar, S., Brown, D.R., Cormier, M.L., Janicek, S., Jones, K.L., King, D.K., Marquez, D.X., Rosenberg, D.E., 2015. Mall walking program environments, features, and participants: a scoping review. Prev. Chronic Dis. 12, 150027.

Flemming, K., Graham, H., Heirs, M., Fox, D., Sowden, A., 2012. Smoking in pregnancy: a systematic review of qualitative research of women who commence pregnancy as smokers.

J. Adv. Nurs. 69, 1023-1036.

Foster, C.E., Brennan, G., Matthews, A., McAdam, C., Fitzsimons, C.F., Mutrie, N., 2011. Recruiting participants to walking intervention studies: a systematic review. Int. J. Behav. Nutr. Phys. Act. 8, 137.

Frey, N.L. 1998. Pilgrim Stories: On and Off the Road to Santiago. University of California Press, Berkeley.

Fullagar, S., 2003. Governing women's active leisure: the gendered effects of calculative rationalities within Australian health policy. Crit. Public Health 13, 47-60.

Gatrell, A.C., 2013. Therapeutic mobilities: walking and 'steps' to wellbeing and health. Health Place 22, 98-106.

Gemzöe, L., 2014. Every minute out there: creating ritual among Swedish pilgrims to Santiago de Compostela. J. Ritual Stud. 28, 65-75.

Grant, G., Machaczek, K., Pollard, N., Allmark, P., 2017. Walking, sustainability and health: findings from a study of a Walking for Health group. Health Soc. Care Comm 25, 1218-1226.

Grant, G., Pollard, N., Allmark, P., Machaczek, K., Ramcharan, P., 2017. The social relations of a health walk group: an ethnographic study. Qual. Health Res. 27, 1701-1712.

Green, J., 2009. 'Walk this way': public health and the social organization of walking. Soc. Theor. Health 7, 20-38.

France, E.F., Cunningham, M., Ring, N., Uny, I., Duncan, E.A.S., Jepson, R.G. et al., 2019. Improving reporting of meta-ethnography: the eMERGe reporting guidance. BMC Med. Res. Methodol. 19, 25.

Guell, C., Panter, J., Jones, N.R., Ogilvie, D., 2012. Towards a differentiated understanding of active travel behaviour: using social theory to explore everyday commuting. Soc. Sci. Med. 75, 233-239.

Hanson, S., Guell, C., Jones, A., 2016. Walking groups in socioeconomically deprived communities: a qualitative study using photo elicitation. Health Place 39, 26-33.

Hanson, S., Jones, A., 2015. Is there evidence that walking groups have health benefits? A systematic review and meta-analysis. Brit. J. Sport. Med. 49, 710-715.

Hynds, H., Allibone, C., 2009. What Motivates People to Participate in Organised Walking Activity? Natural England Commissioned Report 028. 
Ingold, T., 2010. Footprints through the weather-world: walking, breathing, knowing. J. Roy. Anthropol. Inst. 16, S121-S139.

Ingram, M., Ruiz, M., Mayorga, M.T., Rosales, C., 2009. The Animadora Project: identifying factors related to the promotion of physical activity among Mexican Americans with diabetes. Am. J. Health Promot. 23, 396-402.

Ireland, A.V., Finnegan-John, J., Hubbard, G., Scanlon, K., Kyle, R.G., 2019. Walking groups for women with breast cancer: mobilising therapeutic assemblages of walk, talk and place. Soc Sci Med 231, 3846.

Iwata, Y., Dhubháin, A.N., Borphy, J., Roddy, D., Burke, C., Murphy, B., 2016. Benefits of group walking in forests for people with significant mental ill-health. Ecopsychol. 8, 16-26.

Kassavou, A., Turner, A., French, D.P., 2013. Do interventions to promote walking in groups increase physical activity? A meta-analysis. Int. J. Behav. Nutr. Phys. Act. 10, 18.

Kassavou, A., Turner, A., French, D.P., 2015. The role of walkers' needs and expectations in supporting maintenance of attendance at walking groups: a longitudinal multi-perspective study of walkers and walk group leaders. PLoS ONE 10, e0118754.

Katz, S., Calasanti, T., 2015. Critical perspectives on successful aging: does it "appeal more than it illuminates". Gerontologist 55, 26-33.

Lloyd, K., O'Brien, W., Riot, C., 2016. Mothers with young children: caring for the self through the physical activity space. Leisure Sci. 38, 85-99.

Lupton, D., 1995. The Imperative of Health: Public Health and the Regulated Body. Sage, London.

Macpherson, H., 2017. Walkers with visual-impairments in the British countryside: picturesque legacies, collective enjoyments and well-being benefits. J. Rural Stud. 51, 251-258.

Malpass, A., Shaw, A., Sharp, D., Walter, F., Feder, G., Ridd, M., Kessler, D., 2009. "Medication career" or "Moral career"? The two sides of managing antidepressants: a meta-ethnography of patients' experience of antidepressants. Soc. Sci. Med. 68, 154-168.

Markula, P,. 2004. "Tuning into one's self:" Foucault's technologies of the self and mindful fitness. Sociol. Sport J. 21, 302-321.

Middleton, J., 2011. 'Stepping in time': walking, time, and space in the city. Environ. Plann. A 41, 1943-1961.

Mitchell, E.V., (Ed) 1979. The Pleasures of Walking: An Anthology of Works by Belloc, Dickens, Trevelyan, Beerbohm and others. Spur Books, New York.

Morgan-Trimmer, S., Wood, F., 2016. Ethnographic methods for process evaluations of complex health behaviour interventions. Trials 17, 232.

Morris, J.N., Hardman, A.E., 1997. Walking to health. Sports Med. 23, 306-332. 
Morris, S., Guell, C., Pollard, T.M., 2019. Group walking as a "lifeline": understanding the place of walking groups in women's lives. Soc. Sci. Med. 238, 112489.

Nadasen, K., 2008. "Life without line dancing and the other activities would be too dreadful to imagine": an increase in social activity for older women. J. Women Aging 20, 329-342.

Noblit, G.T., Hare, R.D., 1988. Meta-ethnography: Synthesising Qualitative Studies. Sage, Newbury Park.

O’Neill, M., Roberts, B., 2020. Walking Methods: Research on the Move. Routledge, London.

Phillips, R., Knox, A., Langley, E., 2011. Walking for Health: 'Inactive' Walkers - Barriers to Participation, and Activity Substitution. Natural England Commissioned Reports, Number 068.

Phoenix, C., Bell, S., 2019. Beyond "move more": feeling the rhythms of physical activity in mid and later-life. Soc. Sci. Med. 231, 47-54.

Priest, P., 2007. The healing balm effect: using a walking group to feel better. Journal of Health Psychol. 12, 36-52.

Raine, R., Roberts, A., Callaghan, L., Sydenham, Z., Bannigan, K., 2016. Factors affecting sustained engagement in walking for health: a focus group study. Brit. J. Occup. Ther. 80, 183-190.

Resnick, B., Spellbring, A.M., 2000. Understanding what motivates older adults to exercise. J. Gerontol. Nurs. 26, 34-42.

Sallnow, M., 1987. Pilgrims of the Andes: Regional Cults in Cusco. Smithsonian Institution Press, Washington DC.

Schacht, S.P., Unnithan, N.P., 2010. Mall walking and urban sociability. Sociol. Spectrum 11, 351-367.

Sharpley, R., Jepson, D., 2011. Rural tourism: a spiritual experience? Ann. Tourism Res. 38, 52-71.

Sheller, M,. Urry, J., 2006. The new mobilities paradigm. Environ. Plann. A 38, 207-226.

Slavin, S., 2003. Walking as spiritual practice: the pilgrimage to Santiago de Compostela. Body Society 9, 1-18.

Schmucki, B., 2012. "If I walked on my own at night I stuck to well lit areas": gendered spaces and urban transport in $20^{\text {th }}$ century Britain. Res. Transp. Econ. 34, 74-85.

South, J., Giuntoli, G., Kinsella, K., 2012. An Evaluation of the Walking for Wellness Project and the Befriender Role. Natural England Commissioned Reports 118.

South, J., Giuntoli, G., Kinsella, K., Carless, D., Long, J., McKenna, J., 2017. Walking, connecting and befriending: a qualitative pilot study of participation in a lay-led walking group intervention. J.

Transp. Health 5, 16-26. 
Spiegel, A.D., 2011. Categorical difference versus continuum: rethinking Turner's liminal-liminoid distinction. Anthropol. South. Afr. 34, 11-20.

Toye, F., Seers, K., Allcock, N., Briggs, M., Carr, E., Barker, K., 2014. Meta-ethnography 25 years on: challenges and insights for synthesising a large number of qualitative studies. BMC Med. Res.

Methodol. 14, 80.

Turner, V., Turner, E., 1978. Image and Pilgrimage in Christian Culture. Columbia University Press, New York.

Urry, J., 2007. Mobilities. Polity, Cambridge, Massachusetts.

Walking for Health, 2013. Walking for Health Scheme Audit 2012: Report and Analysis.

Ramblers/Macmillan Cancer Support, London.

Warin, M., Moore, V., Davies, M., Turner, K., 2008. Consuming bodies: mall walking and the possibilities of consumption. Health Sociol. Rev. 17, 187-198.

White, S.C., 2017. Relational wellbeing: re-centring the politics of happiness, policy and the self. Policy Polit. 45, 121-136.

Wiltshire, G.R., Fullagar, S., Stevinson, C., 2017. Exploring parkrun as a social context for collective health practices: running with and against the moral imperatives of health responsibilisation. Sociol. Health III. 40, 3-17.

Winkelman, M., Dubisch, J., 2007. Introduction: the anthropology of pilgrimage, in: Dubisch, J. and Winkelman, M., (Eds.), Pilgrimage and Healing. University of Arizona Press, Tucson, pp. ix-xxxvi.

Young, B., Bedford, L., Kendrick, D., Vedhara, K., Robertson, J.F.R., das Nair, R., 2018. Factors influencing the decision to attend screening for cancer in the UK: a meta-ethnography of qualitative research. J. Public Health 40, 315-339. 
Table 1. Details of studies including in the synthesis.

\begin{tabular}{|c|c|c|c|c|c|}
\hline Authors & Country & $\begin{array}{l}\text { Walking group } \\
\text { characteristics }\end{array}$ & Walkers' characteristics & Methods & $\begin{array}{l}\text { Quality } \\
\text { Appraisal }\end{array}$ \\
\hline $\begin{array}{l}\text { Belza et al. } \\
\text { (2017) }\end{array}$ & USA & $\begin{array}{l}\text { Walking groups in malls } \\
\text { and other } \\
\text { nonrecreational public } \\
\text { venues }\end{array}$ & 28 walkers: all over 50 & $\begin{array}{l}\text { Semi-structured } \\
\text { interviews }\end{array}$ & Satisfactory \\
\hline $\begin{array}{l}\text { Browne et } \\
\text { al. (2016) }\end{array}$ & USA & NA & $\begin{array}{l}12 \text { participants: } 42 \% \\
\text { women, aged over } 18 \text {, } \\
42 \% \text { 'Caucasian', } 58 \% \\
\text { African-American, all } \\
\text { with a diagnosis of a } \\
\text { serious mental illness, }\end{array}$ & $\begin{array}{l}\text { Focus groups and } \\
\text { questionnaires }\end{array}$ & Satisfactory \\
\hline $\begin{array}{l}\text { Copelton } \\
(2010)\end{array}$ & USA & $\begin{array}{l}\text { Walking group run by a } \\
\text { community hospital, } \\
\text { targeted to those aged } \\
50 \text { plus. Walked round } \\
\text { perimeter of hospital } \\
\text { buildings on paved } \\
\text { sidewalks and parking } \\
\text { lots }\end{array}$ & $\begin{array}{l}30 \text { walkers: mostly } \\
\text { women, aged 50-79. }\end{array}$ & $\begin{array}{l}\text { Participant- } \\
\text { observation and } \\
\text { interviews }\end{array}$ & Key \\
\hline $\begin{array}{l}\text { Currie et al. } \\
(2016)\end{array}$ & UK & NA & $\begin{array}{l}24 \text { women: with at least } \\
\text { one child born in the last } \\
\text { four years, } 2 \text { spoke } \\
\text { English as a second } \\
\text { language }\end{array}$ & Focus groups & Satisfactory \\
\hline $\begin{array}{l}\text { Doughty } \\
\text { (2013) }\end{array}$ & UK & $\begin{array}{l}\text { A variety of outdoor } \\
\text { led walking groups in } \\
\text { south-east England }\end{array}$ & $\begin{array}{l}40 \text { walkers: aged from } \\
\text { early } 20 \text { s to late } 70 \text { s. }\end{array}$ & $\begin{array}{l}\text { Participant } \\
\text { observation }\end{array}$ & Key \\
\hline $\begin{array}{l}\text { Duncan et } \\
\text { al. (1994) }\end{array}$ & USA & Mall walking group & $\begin{array}{l}14 \text { walkers: } 36 \% \text { women, } \\
\text { aged 61-81, all } \\
\text { 'Caucasian' }\end{array}$ & $\begin{array}{l}\text { Participant } \\
\text { observation and } \\
\text { interviews }\end{array}$ & Satisfactory \\
\hline $\begin{array}{l}\text { Grant et al. } \\
\text { (2017a) and } \\
\text { Grant et al. } \\
\text { (2017b) }\end{array}$ & UK & $\begin{array}{l}\text { Walking for Health } \\
\text { group, split into a } \\
\text { 'strider' group and a } \\
\text { 'stroller' group and } \\
\text { moving through } \\
\text { predominantly open } \\
\text { countryside and } \\
\text { farmland }\end{array}$ & $\begin{array}{l}19 \text { walkers: } 68 \% \text { women, } \\
\text { aged } 58-89\end{array}$ & $\begin{array}{l}\text { Participant } \\
\text { observation and } \\
\text { interviews }\end{array}$ & Key \\
\hline $\begin{array}{l}\text { Hanson et } \\
\text { al. (2016) }\end{array}$ & UK & $\begin{array}{l}\text { Group run by the } \\
\text { National Health Service } \\
\text { in a deprived coastal } \\
\text { town for people } \\
\text { referred by their GP }\end{array}$ & $\begin{array}{l}10 \text { walkers: } 60 \% \text { women, } \\
60 \% \text { aged } 50-70\end{array}$ & $\begin{array}{l}\text { Photo-elicitation } \\
\text { interviews }\end{array}$ & Key \\
\hline $\begin{array}{l}\text { Hynds and } \\
\text { Allibone } \\
\text { (2009) }\end{array}$ & UK & $\begin{array}{l}\text { Urban walking groups } \\
\text { run by Walking for } \\
\text { Health }\end{array}$ & $\begin{array}{l}29 \text { walkers: } 59 \% \text { women, } \\
\text { aged } 35-84\end{array}$ & Focus groups & Satisfactory \\
\hline $\begin{array}{l}\text { Ingram et } \\
\text { al. (2009) }\end{array}$ & USA & $\begin{array}{l}\text { Walking groups for } \\
\text { people with diabetes in } \\
\text { two Mexican-American } \\
\text { communities in Tucson, }\end{array}$ & $\begin{array}{l}20 \text { walkers: } 85 \% \text { women, } \\
\text { aged } 33-95 \text {, all Mexican- } \\
\text { American, all with } \\
\text { diabetes. }\end{array}$ & Focus groups & Satisfactory \\
\hline
\end{tabular}




\begin{tabular}{|c|c|c|c|c|c|}
\hline & & $\begin{array}{l}\text { Arizona, organised by a } \\
\text { community agency }\end{array}$ & & & \\
\hline $\begin{array}{l}\text { Ireland et } \\
\text { al. (2019) }\end{array}$ & UK & $\begin{array}{l}\text { Three walking groups } \\
\text { for people affected by } \\
\text { breast cancer run by a } \\
\text { charity in the north of } \\
\text { England, following } \\
\text { routes accessible to } \\
\text { people of all abilities } \\
\text { and fitness levels } \\
\text { through } \\
\text { parks/woodlands/along } \\
\text { a canal }\end{array}$ & $\begin{array}{l}19 \text { walkers, } 13 \text { walk } \\
\text { leaders: nearly all } \\
\text { women with a breast } \\
\text { cancer diagnosis }\end{array}$ & $\begin{array}{l}\text { Questionnaires } \\
\text { and interviews }\end{array}$ & Key \\
\hline $\begin{array}{l}\text { Iwata et al. } \\
\text { (2016) }\end{array}$ & Ireland & $\begin{array}{l}\text { Forest walks for people } \\
\text { with significant mental } \\
\text { ill-health. Participants } \\
\text { gathered in town and } \\
\text { were taken to the } \\
\text { forest sites by } \\
\text { community buses }\end{array}$ & $\begin{array}{l}15 \text { walkers: } 80 \% \text { women, } \\
\text { aged } 32-72 \text {, all with } \\
\text { mental ill-health }\end{array}$ & $\begin{array}{l}\text { Interviews and } \\
\text { questionnaires }\end{array}$ & Satisfactory \\
\hline $\begin{array}{l}\text { Kassavou et } \\
\text { al. (2015) }\end{array}$ & UK & $\begin{array}{l}\text { Walking for Health } \\
\text { groups run by an urban } \\
\text { local authority in the } \\
\text { midlands of England }\end{array}$ & $\begin{array}{l}8 \text { walkers: } 88 \% \text { women, } \\
\text { aged } 56-64 \\
8 \text { walk leaders: } 63 \% \\
\text { women }\end{array}$ & Interviews & Satisfactory \\
\hline $\begin{array}{l}\text { Macpherson } \\
\text { (2017) }\end{array}$ & UK & $\begin{array}{l}\text { Led 5-8 mile walks for } \\
\text { visually impaired } \\
\text { people walking with a } \\
\text { volunteer sighted guide } \\
\text { in highland areas of } \\
\text { natural beauty, } \\
\text { organised by a } \\
\text { collective of people } \\
\text { with visual- } \\
\text { impairments and } \\
\text { volunteers or by a } \\
\text { disabled holidays } \\
\text { charity }\end{array}$ & $\begin{array}{l}19 \text { walkers: } 42 \% \text { women, } \\
\text { aged } 22-80,89 \% \text { White, } \\
5 \%(1) \text { of Iranian and } 5 \% \\
\text { (1) one of Afro- } \\
\text { Caribbean descent, all } \\
\text { visually impaired or blind }\end{array}$ & $\begin{array}{l}\text { Participant } \\
\text { observation and } \\
\text { interviews }\end{array}$ & Key \\
\hline $\begin{array}{l}\text { Morris et al. } \\
\text { (2019) }\end{array}$ & UK & $\begin{array}{l}\text { Walking groups in } \\
\text { deprived areas of } \\
\text { north-east England }\end{array}$ & $\begin{array}{l}37 \text { walkers: } 100 \% \\
\text { women, } 81 \% \text { aged 51-80, } \\
84 \% \text { White British, 12\% } \\
\text { British South Asian, 4\% } \\
\text { other }\end{array}$ & & \\
\hline $\begin{array}{l}\text { Phillips et } \\
\text { al. (2011) }\end{array}$ & UK & NA & $\begin{array}{l}20 \text { ex-walkers: } 75 \% \\
\text { women, most aged over } \\
55,90 \% \text { White, } 10 \% \\
\text { Black or Minority } \\
\text { Ethnicity. }\end{array}$ & $\begin{array}{l}\text { Interviews and } \\
\text { telephone survey }\end{array}$ & Satisfactory \\
\hline $\begin{array}{l}\text { Priest } \\
(2007)\end{array}$ & UK & $\begin{array}{l}\text { A walking group run by } \\
\text { a mental health day } \\
\text { service in a rural town } \\
\text { surrounded by } \\
\text { countryside }\end{array}$ & $\begin{array}{l}14 \text { walkers: } 29 \% \text { women, } \\
\text { aged } 26-47\end{array}$ & $\begin{array}{l}\text { Participant } \\
\text { observation, } \\
\text { interviews and } \\
\text { group discussion }\end{array}$ & Key \\
\hline
\end{tabular}




\begin{tabular}{|c|c|c|c|c|c|}
\hline $\begin{array}{l}\text { Raine et al. } \\
\text { (2017) }\end{array}$ & UK & $\begin{array}{l}\text { One walking group for } \\
\text { people who had } \\
\text { recently had a cardiac } \\
\text { event that had ceased } \\
\text { due to poor } \\
\text { attendance, one for } \\
\text { school parents in an } \\
\text { area considered to } \\
\text { have a high prevalence } \\
\text { of inactivity }\end{array}$ & $\begin{array}{l}8 \text { walkers: } 75 \% \text { women } \\
6 \text { group leaders: } 67 \% \\
\text { women }\end{array}$ & Focus groups & Satisfactory \\
\hline $\begin{array}{l}\text { Resnick and } \\
\text { Spellbring } \\
(2000)\end{array}$ & USA & $\begin{array}{l}\text { Walking groups run by } \\
\text { a continuing care } \\
\text { retirement community } \\
\text { walking inside or, when } \\
\text { weather allowed, } \\
\text { outside }\end{array}$ & $\begin{array}{l}23 \text { walkers: } 91 \% \text { women, } \\
\text { average age } 81 \text {, all White }\end{array}$ & $\begin{array}{l}\text { Interviews and } \\
\text { questionnaires }\end{array}$ & Satisfactory \\
\hline $\begin{array}{l}\text { Schacht and } \\
\text { Unnithan } \\
(1991)\end{array}$ & USA & A mall walkers club & $\begin{array}{l}6 \text { walkers: } 67 \% \text { women } \\
\text { (interviewed) }\end{array}$ & $\begin{array}{l}\text { Observation and } \\
\text { interviews }\end{array}$ & Satisfactory \\
\hline $\begin{array}{l}\text { South et al. } \\
\text { (2012) and } \\
\text { South et al. } \\
\text { (2017) }\end{array}$ & UK & $\begin{array}{l}\text { Walking for Health } \\
\text { groups in rural areas, } \\
\text { towns and coastal } \\
\text { villages in the north of } \\
\text { England and run by } \\
\text { local voluntary sector } \\
\text { organisations for the } \\
\text { county council }\end{array}$ & $\begin{array}{l}77 \text { walkers: } 61 \% \text { women, } \\
\text { most aged } 65-84,99 \% \\
\text { White. }\end{array}$ & $\begin{array}{l}\text { Focus groups and } \\
\text { interviews }\end{array}$ & Key \\
\hline $\begin{array}{l}\text { Warin et al. } \\
(2008)\end{array}$ & Australia & $\begin{array}{l}\text { Two mall walking } \\
\text { groups in a } \\
\text { disadvantaged suburb } \\
\text { of a major Australian } \\
\text { city }\end{array}$ & $\begin{array}{l}15 \text { regular walkers plus } \\
\text { less regular walkers: } \\
\text { mostly women over } 50\end{array}$ & $\begin{array}{l}\text { Participant } \\
\text { observation }\end{array}$ & Key \\
\hline
\end{tabular}

Ethnicity was included where reported, and walk leaders are only included here if their data contributed to the results incorporated into our review 
Table 2. Formation of third order constructions from second order constructs.

\begin{tabular}{|c|c|c|c|c|c|c|c|c|c|c|c|}
\hline $\begin{array}{l}\text { Third-order } \\
\text { Constructs }\end{array}$ & $\begin{array}{c}\text { Working } \\
\text { towards } \\
\text { health }\end{array}$ & $\begin{array}{l}\text { Experiencing } \\
\text { embodied } \\
\text { benefits }\end{array}$ & $\begin{array}{l}\text { Attachment } \\
\text { to walking }\end{array}$ & $\begin{array}{l}\text { Experiencing } \\
\text { a sense of } \\
\text { achievement } \\
\text { and } \\
\text { confidence }\end{array}$ & $\begin{array}{l}\text { Providing a } \\
\text { sense of } \\
\text { commitment } \\
\text { and routine }\end{array}$ & $\begin{array}{l}\text { A haven } \\
\text { away } \\
\text { from } \\
\text { everyday } \\
\text { life }\end{array}$ & $\begin{array}{c}\text { A } \\
\text { meaningful } \\
\text { connection } \\
\text { with the } \\
\text { outdoor } \\
\text { environment }\end{array}$ & $\begin{array}{l}\text { Experiencing } \\
\text { social } \\
\text { connection }\end{array}$ & \begin{tabular}{|c|} 
Experiencing \\
acceptance \\
and \\
belonging
\end{tabular} & $\begin{array}{l}\text { Enjoyment } \\
\text { of fleeting } \\
\text { sociability }\end{array}$ & $\begin{array}{l}\text { Feeling } \\
\text { safe }\end{array}$ \\
\hline $\begin{array}{l}\text { Contribution } \\
\text { to Line of } \\
\text { Argument }\end{array}$ & \multicolumn{2}{|c|}{$\begin{array}{l}\text { Seeking and enjoying } \\
\text { health and fitness }\end{array}$} & $\begin{array}{l}\text { Attachment } \\
\text { to walking }\end{array}$ & \multicolumn{2}{|c|}{$\begin{array}{l}\text { Providing purpose and } \\
\text { confidence }\end{array}$} & \multicolumn{2}{|c|}{$\begin{array}{l}\text { A peaceful and } \\
\text { contemplative shared } \\
\text { respite from everyday } \\
\text { life }\end{array}$} & \multicolumn{4}{|c|}{ Mobile companionship } \\
\hline Key papers & & & & & & & & & & & \\
\hline $\begin{array}{l}\text { Copelton } \\
2010\end{array}$ & $\checkmark$ & & & & & & & $\checkmark$ & $\checkmark$ & & $\checkmark$ \\
\hline Doughty 2013 & & & & & & $\checkmark$ & $\checkmark$ & $\checkmark$ & & $\checkmark$ & \\
\hline $\begin{array}{l}\text { Grant et al. } \\
2017 a, 2017 b\end{array}$ & $\checkmark$ & & $\checkmark$ & & $\checkmark$ & & $\checkmark$ & $\checkmark$ & $\checkmark$ & $\checkmark$ & $\checkmark$ \\
\hline $\begin{array}{l}\text { Hanson et al. } \\
2016\end{array}$ & $\checkmark \quad D$ & $\checkmark$ & $\checkmark$ & $\checkmark$ & & $\checkmark$ & & D & D & $\checkmark$ & \\
\hline $\begin{array}{l}\text { Ireland et al. } \\
2019\end{array}$ & & & & & & $\checkmark$ & $\checkmark$ & $\checkmark$ & $\checkmark$ & & \\
\hline $\begin{array}{l}\text { Macpherson } \\
2017\end{array}$ & & $\checkmark$ & & $\checkmark$ & $\checkmark$ & & & $\checkmark$ & & & \\
\hline $\begin{array}{l}\text { Morris et al. } \\
2019\end{array}$ & $\checkmark$ & & & $\checkmark$ & $\checkmark$ & & $\checkmark$ & $\checkmark$ & & & $\checkmark$ \\
\hline Priest 2007 & & & & $\checkmark$ & $\checkmark$ & $\checkmark$ & $\checkmark$ & & $\checkmark$ & & $\checkmark$ \\
\hline $\begin{array}{l}\text { South et al. } \\
2012,2017\end{array}$ & $\checkmark$ & $\checkmark$ & & $\checkmark$ & & $\checkmark$ & $\checkmark$ & $\checkmark \quad D$ & & & $\checkmark$ \\
\hline $\begin{array}{l}\text { Warin et al. } \\
2008\end{array}$ & $\checkmark$ & & & & & & & $\checkmark$ & & & $\checkmark$ \\
\hline
\end{tabular}




\begin{tabular}{|c|c|c|c|c|c|c|c|c|c|c|}
\hline $\begin{array}{l}\text { Satisfactory } \\
\text { papers }\end{array}$ & & & & & & & & & & \\
\hline $\begin{array}{l}\text { Belza et al. } \\
2017\end{array}$ & & $\checkmark$ & & $\checkmark$ & $\checkmark$ & & $\checkmark$ & $\checkmark$ & & $\checkmark$ \\
\hline $\begin{array}{l}\text { Browne et al. } \\
2016\end{array}$ & & & & & & & & $\begin{array}{ll} & D\end{array}$ & & \\
\hline $\begin{array}{l}\text { Currie et al. } \\
2016\end{array}$ & & & $\mathrm{D}$ & & $\mathrm{D}$ & & & $\begin{array}{ll}\checkmark & D\end{array}$ & & \\
\hline $\begin{array}{l}\text { Duncan et al. } \\
1994\end{array}$ & $\checkmark$ & $\checkmark$ & & & $\checkmark$ & & & $\checkmark$ & $\checkmark$ & $\sqrt{ }$ \\
\hline $\begin{array}{l}\text { Hynds and } \\
\text { Allibone } 2009\end{array}$ & $\checkmark$ & & $\checkmark$ & $\checkmark$ & $\checkmark$ & & $\begin{array}{ll}\checkmark & D\end{array}$ & $\checkmark$ & $\checkmark$ & $\mathrm{D}$ \\
\hline $\begin{array}{l}\text { Ingram et al. } \\
2009\end{array}$ & & & $\checkmark$ & $\checkmark$ & $\checkmark$ & & & $\checkmark$ & $\checkmark$ & \\
\hline $\begin{array}{l}\text { Iwata et al. } \\
2016\end{array}$ & & & & & $\checkmark$ & $\checkmark$ & $\begin{array}{ll} & D\end{array}$ & $\checkmark$ & $\checkmark$ & \\
\hline $\begin{array}{l}\text { Kassavou et } \\
\text { al. } 2015\end{array}$ & $\checkmark$ & $\checkmark$ & & $\checkmark$ & & & & $\checkmark$ & & $\sqrt{ }$ \\
\hline $\begin{array}{l}\text { Phillips et al. } \\
2011\end{array}$ & $\checkmark$ & & & & & $\checkmark$ & $\checkmark$ & $\begin{array}{ll} & D\end{array}$ & & $\checkmark$ \\
\hline $\begin{array}{l}\text { Raine et al. } \\
2017\end{array}$ & & & & & & $\checkmark$ & $\checkmark$ & $\checkmark$ & & \\
\hline $\begin{array}{l}\text { Resnick and } \\
\text { Spellbring } \\
2000\end{array}$ & $\begin{array}{ll}\checkmark & D\end{array}$ & $\begin{array}{ll}\checkmark & D\end{array}$ & $\begin{array}{ll}\checkmark & D\end{array}$ & $\checkmark$ & & & & & & \\
\hline $\begin{array}{l}\text { Schacht and } \\
\text { Unnithan } \\
1991 \\
\end{array}$ & $\checkmark$ & $\checkmark$ & $\checkmark$ & $\checkmark$ & & & & & & $\sqrt{ }$ \\
\hline
\end{tabular}

$D$ indicates a disconfirming contribution. 